\title{
PENDATAAN DAN DIGITALISASI NASKAH MELAYU KUNO DI KABUPATEN KAMPAR
}

\author{
Evizariza, Iik Idayanti \\ Fakultas Ilmu Budaya, Universitas Lancang Kuning, Pekanbaru, \\ evizariza@yahoo.com
}

\begin{abstract}
Manuscript is a cultural heritage of ancestors in the past. In the manuscripts there are many sources of information and knowledge of the community that were developing at that time. One of which was Malay manuscripts. Currently, the existence of Malay manuscripts is widely spread and recorded in various regions, both inside and outside the country. However, there are still many Malay manuscripts that are still owned by individuals, becoming private collections, such as Malay manuscripts in the Kampar region. These manuscripts are still unrecorded and in vulnerable conditions with damage and even lost or sold. Judging from these realities, actions are needed to save the manuscripts, such as collecting and digitalizating. By so, eventhough saving the manuscripts physically is hard, but we can get the contents of the text. Thus, the research on the physical obejct will be studied using a codicological approach, and the text content will be analyzed philologically.
\end{abstract}

Keywords: Manuscripts, collecting, digitalizing, Kampar manuscripts

\section{A. Pendahuluan}

Melayu memiliki peninggalan budaya yang sangat banyak, salah satunya berwujud naskah kuno. Hal ini terbukti dari banyaknya jumlah naskah Melayu yang tersebar dan tercatat di berbagai wilayah baik di dalam dan luar negeri. Achadiati Ikram (1997: 36) menyebutkan, peninggalan naskah lama dalam bahasa Melayu termasuk yang paling besar jumlahnya, di samping bahasa Bali dan Jawa. Naskah lama yang jumlahnya banyak tersebut membuktikan betapa penting dan berharganya aset budaya yang kita miliki, dalam hal ini berkaitan dengan isi kandungan naskah yang luas dan beragram, meliputi bidang agama, sejarah, sastra, mitologi, seni, hukum, ilmu kemasyarakatan, cerita rakyat, myte, legenda, adat-istiadat dan serbaserbi (Pigeaud dalam Lantiani, 1996: $1)$.

Salah satu wilayah yang memiliki peninggalan naskah Melayu kuno di Provinsi Riau adalah Kabupaten Kampar. Kampar merupakan wilayah yang memiliki sejarah masa lalu yang 
belum sepenuhnya tergali. Padahal banyak bukti sejarah peninggalan masa lampau yang masih ada. Namun hingga saat ini, kondisi peninggalannya kuranglah terawat dan atau hilang, salah satunya peninggalan kerajaan masa Sultan Mahmud pada abad-15, seorang raja dari Malaka yang melarikan diri dari serangan Portugis ke wilayah Kampar dan mendirikan Kerajaan Kampar. Peninggalan tersebut berwujud bangunan, seperti masjid Kubro Koto Perambahan dan wujud benda, seperti keris, tombak, pedang, peti, hingga naskah kuno (DetakKampar, 2014).

Zaman dulu, Kampar juga dikenal sebagai pusat lahirnya ulama-ulama terkemuka yang menyebarkan ajaran Tarikat Ahli Sufiyah, terutama Tarekat Naqsyabandiyah. Tokoh ulama tersebut, ialah Maulana Syekh Abdul Wahab Rokan Al-Khalidi dan Syekh Abdul Ghani Batu Basurek Kampar (1811-1961 M). Pendidikan awal para ulama tersebut berasal dari surausurau yang menjamur di seantero Minangkabau kala itu. Kedua ulama besar inilah yang cukup terkenal di Pantai Timur Sumatera serta memiliki banyak murid yang merupakan pejabat dan ulama (Putra, 2011). Terkait tradisi pernaskahan, kala itu, di surau-surau terdapat banyak aktivitas menulis naskah yang dilakukan oleh murid-murid tarekat. Saat ini keberadaannya berserakan dan tersebar di masyarakat (Pramono, 2008).

Melihat kondisi tersebut, perlu dilakukan tindakan berwujud penelitian preservasi mendata dan mendigitalisasi naskah-naskah yang dimiliki oleh masyarakat di wilayah Kampar. Kegiatan ini perlu segera dilakukan, karena objek yang dibahas dalam penelitian ini sangat rentan dengan kerusakan, hilang atau berpindah tangan. Harapan peneliti, hasil kajian ini dapat dibaca, dijadikan sumber informasi di dunia pendidikan, dan diambil manfaat lainnya oleh masyarakat luas. Adapun tujuan dari penelitian ini adalah pendataan dan digititalisasi naskah kuno Melayu di Kabupaten Kampar.

\section{Tinjauan Pustaka}

Pendataan dan pendigitalisasian naskah kuno Melayu di Kabupaten Kampar sudah pernah dilakukan oleh Agus Iswanto dan diterbitkan dalam Jurnal Lektur Keagamaan pada tahun 2015. Penelusuran naskah yang dilakukan Agus Iswanto berdasarkan informasi yang pernah dihimpun oleh Syukri yang merupakan bagian dari Tim Penelitian Pemetaan Naskah Klasik di Riau, UIN Riau pada tahun 2009, tepatnya di 4 Kabupaten di Provinsi Riau, salah satunya Kabupaten Kampar (Erni, Sukma. dkk dalam Iswanto Agus, Jurnal Lektur Keagamaan, 2015: 431-454). 
Isi laporan Agus Iswanto lebih terpusat pada pendataan naskah kuna keagamaan bertemakan keagamaan, terutama Tauhid di wilayah Kotamadya Pekanbaru dan Kabupaten Kampar. Khusus di area Kampar, naskah kuna ditemukan di tiga wilayah, yaitu Desa Rumbio Kecamatan Kampar, Desa Ranah Kecamatan KamparTimur, dan Desa Naga Beralih Kecamatan Kampar Utara. Total naskah yang ditemukan di desa tersebut berjumlah 5 naskah dan isi naskah mengandung ajaran tauhid (ibid, 2015). Bagi wilayah Kampar yang dulunya merupakan basis ulama di daratan Sumatera, jumlah naskah tersebut masih tergolong sedikit, sehingga perlu dilakukan penelusuran lapangan lebih lanjut.

Penelitian lainnya di Kabupaten Kampar masih belum ada atau belum terpublikasikan lagi. Penelitian terkait pendataan naskah di wilayah Riau selama ini banyak terfokus di wilayah Pulau Penyengat yang saat ini masuk dalam Provinsi Kepulauan Riau (lihat Mu'jizah dan Rukmi, 2009; Hamidy, 1983, 1985). Sehingga dapat disimpulkan, penelitian terkait pendataan dan digitalisai naskah, khususnya naskah di Kabupaten Kampar Provinsi Riau masih sangat jarang dilakukan.

\section{B. Metode Penelitian}

Penelitian ini terkait dengan pendataan dan pendokumentasian naskah, dalam dunia filologi, kajian terkait disebut dengan kodikologi. Dengan kata lain, naskah-naskah yang ditemukan di rumah-rumah penduduk di Kabupaten Kampar akan didokumentasikan, diteliti, dan dikaji menggunakan pendekatan kodikologi.

\section{Rancangan Penelitian}

Tahap pertama penelitian adalah mengumpulkan informasi dan bahan pustaka yang sesuai untuk membuat desain penelitian dengan mencakup seluruh unsur naskah dalam formatisian yang nantinya perlu diisi.

Tahap kedua, melakukan penelitian lapangan dengan berbekal format isian deskripsi naskah. Semua naskah yang ditemukan difoto menggunakan kamera digital, sedangkan fisik naskahnya dicatat seteliti mungkin, yang meliputi antara lain: judul, tebal naskah, jilidan, tinta, bahasa, aksara, iluminasi, dan lain sebagainya.

Tahap ketiga, adalah proses pengujian data, yaitu dengan cara memeriksa dan mencocokkan data foto naskah dengan data format isian deskripsi naskah.

Tahap terakhir adalah menganalisis data. Pada tahap ini semua data yang telah terkumpul dikaji, lalu dikelompokkan berdasarkan genre, bahasa, aksara, kandungan isi teks, dan lain sebagainya. 


\section{Hasil dan Pembahasan}

Penelusuran data naskah-naskah Melayu di wilayah Kabupaten Kampar dilakukan dengan cara mencari informasi keberadaan naskah dari mahasiswa-mahasiswa dan kolega beberapa dosen FIB Unilak. Selain itu, peneliti juga mewawancarai pihak Dinas Kebudayaan Provinsi Riau, Bapak Yoserizal Zein untuk memperoleh informasi terkait dengan keberadaan naskah di wilayah Kabupaten Kampar.

Hasil wawancara, Bapak Yoserizal menyambut baik upaya pendataan dan pendigitalisasian naskah terutama di Provinsi Riau, terkhusus Kabupaten Kampar. Sebenarnya, upaya pendataan naskah di Kabupaten tersebut sudah pernah dilakukan, namun terdapat kendala yang terjadi ketika di lapangan, hingga tidak mendapatkan hasil apapun. Salah satu hambatannya adalah masyarakat yang kurang koorperatif terhadap pemerintah dalam memberikan informasi koleksi naskah yang dimilikinya. Dengan adanya penelitian ini, pihak Dinas Kebudayaan mengharapkan usaha yang dilakukan peneliti membuahkan hasil, setidaknya hasil pendataan dan pendokumentasian dapat dilaporkan juga ke pihaknya.

Tahap berikutnya, setelah pengumpulan informasi dari kolega dan masyarakat, peneliti bersama beberapa mahasiswa mengunjungi lokasi penyimpanan naskah, yang kebanyakan berada di rumah warga dan merupakan koleksi pribadi. Terkadang ada pemilik naskah yang bersedia dikunjungi, namun ketika rombongan peneliti dan mahasiswa sampai di lokasi, si pemilik naskah tidak mengizinkan naskahnya didata. Hal tersebut merupakan kendala yang biasa ditemui ketika di lapangan. Dan kunjungan tanpa hasil tersebut tidak akan peneliti laporkan dalam tulisan ini. Secara umum, naskah yang sudah berhasil kami data berjumlah total 13 naskah yang dimiliki oleh dua orang warga. Objek yang kami teliti dibatasi naskah yang berwujud naskah tulisan tangan.

Kunjungan pertama ke rumah Bapak Abdul Latif yang berlokasi di Bangkinang, Kabupaten Kampar. Kunjungan dilakukan pada tanggal 21 September 2016. Di kediamannya, tersimpan 12 naskah dengan kondisi yang beragam.

Kunjungan kedua ke rumah Bosu Ani yang berada di Desa Kuntu, Kecamatan Gunung Sahilan, Kabupaten Kampar. Kunjungan ini dilakukan pada tanggal 04 April 2017. Naskah berjumlah 1 naskah. Namun, saat itu naskah tidak disimpan di kediaman Bosu Ani, melainkan di 
rumah anaknya yang merupakan tokoh adat setempat.

Rincian mengenai jumlah dan identitas naskah yang berada di Kabupaten Kampar, berikut deskripsi ringkasnya:

\section{Rumah Bapak Abdul Latif}

Di rumah Bapak Abdul Latif tersimpan 12 naskah tulisan tangan dengan deskripsi sebagai berikut:

Naskah A, berbahasa dan beraksara Arab, isi teks mengenai kumpulan hadist. Jumlah halaman sebanyak 157 halaman. Naskah berukuran 15,3 x 9,5 cm, dan tanpa memiliki sampul. Alas tulis naskah berupa kertas Eropa dengan watermark bertuliskan GILING, 1828 (?).Jumlah baris perhalaman 9 baris. Kondisi naskah lapuk, tidak lengkap, dan rusak. Terdapat lubang besar tepat ditengah lembaran teks dari halaman awal hingga halaman ke 26 dengan ukuran lubang yang semakin menuju ke halaman tengah, semakin kecil ukurannya. Pada halaman 5 dan 39 terdapat iluminasi bermotif floral dengan tinta merah dan biru. Terdapat catchword pada halaman tertentu saja. Bekas pena tebal, hanya tembus sedikit tetapi tidak sampai merusak teks. Terdapat rubrikasi dengan tinta warna merah. Tidak ditemukan kolofon dalam teks, namun pada halaman terakhir terdapat tulisan latin dengan tinta biru dengan bacaan Sjamsir. Dikarenakan halaman awal dan akhir teks mengalami kerusakan, peneliti tidak dapat membaca dengan jelas teks yang ditulis pada halaman tersebut.

Naskah B, berbetuk gulungan dan disimpan pada batang bambu. Naskah berisi salah satu surah dalam AlQur'an, yaitu surah Al-Waqiah menggunakan aksara Arab. Ukuran naskah $29,5 \mathrm{~cm} \times 14,5 \mathrm{~cm}$ dengan blok teks tinta warna merah dengan ukuran $8,5 \mathrm{~cm}$ x $6,5 \mathrm{~cm}$. Sampul naskah adalah batang bambu. Jenis alas tulis adalah karton tebal kokoh berwarna cokelat berjumlah 38 halaman. Jumlah baris 7 baris perhalaman. Seluruh halaman dihiasi dengan iluminasi dengan tinta warna merah. Terdapat rubrikasi di tiap akhir ayat mengunakan tinta warna merah. Ukuran tulisan sedang, dengan bekas pena yang memudar, sehingga aksara tidak terbaca dengan jelas (buram). Naskah sebenarnya lengkap dari awal hingga akhir, namun karena aksara banyak yang buram, maka kejelasan bacaaan cukup minim.

Naskah C, merupakan naskah beraksara Arab dalam bentuk AlQur' an dengan sampul berasal dari kulit binatang. Ukuran halaman 47,5 $\mathrm{cm}$ x $36 \mathrm{~cm}$. Alas tulis berupa kertas karton tebal berwarna coklat tua dan dalam kondisi kokoh. Jumlah halaman sebanyak 230 halaman dengan 
halaman kosong masing-masing pada 2 lembar awal dan lembar akhir. Jumlah baris perhalaman berbeda, pada halaman 1 atas 9 baris perhalaman, sedangkan halaman 2 hingga akhir terdiri dari 16 baris. Ukuran tulisan tergolong besar dengan rubrikasi berwarna merah dan tinta yang dipakai berwarna emas.

Naskah D, merupakan naskah beraksara Arab dalam wujud gulung kecil berwarna ungu dengan tinta berwarna emas. Naskah dalam kondisi kokoh, beraksara Arab tanpa harakat. Ukuran naskah $58 \mathrm{~cm}$ x $5 \mathrm{~cm}$ dengan alas tulis terbuat dari kertas karton tebal. Naskah dalam bentuk gulungan dengan sampul hitam yang direkatkan menyatu dengan teks utama. Naskah dengan sistem penulisan timbal balik yang terdiri atas 21 halaman. Jumlah baris perhalaman tidak tetap di setiap halaman. Terdapat ilmuminasi naskah dengan gambar berbentuk keris, hewan harimau, kalajengking, buaya, dan elang. Kondisi naskah cukup baik dan kokoh. Teks ditulis menggunakan tinta berwarna emas dengan ukuran aksara yang tergolong kecil dan tertulis secara tipis. Mutu tulisan sukar dibaca. Terkait isi dan ukuran naskah, teks berisi doa-doa.

Naskah E, merupakan naskah beraksara gundul dan berangka Arab dengan ukuran naskah yang cukup kecil yaitu $72 \mathrm{~cm} \mathrm{x} 3 \mathrm{~cm}$. Sampul terbuat dari kulit binatang dengan kotak penyimpanan naskah yang terbuat dari besi berwarna emas bersampul kain hitam. Kondisi naskah cukup baik dan kokoh. Warna alas tulis terbuat dari karton berwarna hitam dan dilipat secara zigzag yang terdiri dari 21 halaman. Jumlah baris perhalaman di setiap halaman berbedabeda. Dilihat dari ukuran naskah dan isi teks, naskah termasuk dalam naskah doa-doa.

Naskah F adalah naskah berukuran kecil yaitu $75 \mathrm{~cm}$ x 3,5 cm dalam kondisi baik dan kokoh. Sampul naskah terbuat dari kulit binatang berwarna putih. Jenis alas tulis terbuat dari karton berwarna hitam dengan tinta berwarna emas. Naskah dilipat secara zigzag dengan jumlah halaman 57 halaman dengan jumlah baris ratarata 3 baris perhalaman. Dilihat dari isi teks, naskah termasuk dalam naskah doa-doa.

Naskah G, merupakan naskah yang terdiri atas beberapa lembar saja dan kondisinya sudah dilaminating menggunakan plastik transparan. Lembaran naskah tersebut beraksara Arab dan berisi tentang ayat-ayat AlQuran. Naskah total terdiri atas 6 lembar (12 halaman) dengan ukuran naskah 34 × $23 \mathrm{~cm}$, blog teks 24 x 11 $\mathrm{cm}$. Naskah tidak memiliki sampul dengan alas tulis terbuat dari kertas Eropa berwarna cokelat tanpa ada 
keterangan watermark. Keadaan naskah tidak lengkap dan lembaran yang tersisa di dalam plastik laminating sebagian rusak. Rubrikasi menggunakan tinta warna merah.

Naskah H, termasuk dalam jenis naskah Al-Quran, dengan ukuran naskah 47,5x36 cm. Sampul terbuat dari kulit binatang. Alas tulis terbuat dari kertas karton tebal berwarna coklat tua dan dalam kondisi baik dan kokoh. Total halaman terdiri dari 196 halaman dengan kim 1 halaman. Pada halaman 1 dan 2 terdiri dari 8 baris perhalaman dengan dihiasai iluminasi berwarna merah, sedangkan pada halaman 3 hingga 196 terdiri atas 17 baris perhalaman tanpa hiasan. Jenis aksara Arab dengan tulisan tebal dan mudah dibaca.

Naskah I, termasuk dalam jenis naskah kitab beraksara dan berbahasa Arab. Naskah tidak lengkap dan terdiri atas 170 halaman dengan ukuran $21 \mathrm{x}$ $14 \mathrm{~cm}$. Penomoran halaman tidak dicantumkan. Naskah tidak bersampul dengan alas tulis terbuat dari kertas Eropa dengan watermark bertuliskan budler. Jumlah baris perhalaman 19 baris dengan tulisan yang mudah dibaca. Penulisan aksara menggunakan tinta merah dan hitam. Isi teks termasuk dalam jenis naskah kitab.

Naskah J, termasuk dalam naskah kitab dengan aksara dan bahasa Arab.
Naskah tidak bersampul, lapuk dan tidak lengkap dengan ukuran naskah $21,5 \times 17 \mathrm{~cm}$. Alas tulis terbuat dari kertas Eropa dengan jumlah halaman 102 halaman terdiri atas 11 baris di tiap halamannya. Watermark bertuliskan propatria tanpa garis pengarah. Berdasarkan keterangan watermark dapat diketahui kertas dibuat di Inggris pada tahun 1764. Tulisan berukuran sedang dan tebal dengan aksara ditulis menggunakan tinda hitam.

Naskah K, termasuk jenis naskah kitab karena berisi tentang hadisthadist. Naskah beraksara dan berbahasa Arab. Alas tulis naskah terbuat dari kerta Eropa berwarna kecoklatan dengan watermark bertuliskan C.L.B. Jumlah halaman 84 halaman terdiri atas 12 baris perhalaman. Warna tulisan menggunakan tinta berwarna hitam dan merah. Naskah tidak lengkap dan tidak bersampul.

Naskah L, termasuk dalam jenis sastra kitab kondisi naskah tidak lengkap dan lapuk. Ukuran naskah 21 $\mathrm{x} 14$ halaman. Alas tulis terbuat dari kertas Eropa berwarna kecoklatan dengan watermark bergambar mahkota. Berdasarkan watermark dapat diketahui bahwa kertas dibuat di The Hague, Belanda oleh E. Kempfer pada tahun 1729. Penomoran halaman tidak 
dicantumkan, namun berdasarkan penghitungan halaman, naskah terdiri atas 50 halaman, dan tiap halaman terdiri atas 19 baris perhalaman. Ukuran tulisan sedang, tipis dan mudah dibaca. Akhir teks terbaca ".... Abdullah Syataroni”. Terdapat tulisan di luar teks yang menandakan keterangan terkait teks utama.

\section{Naskah Bosu Ani}

Naskah yang dimiliki oleh Bosu Ani berjumlah 1 naskah, dan saat ini keberadaanya disimpan oleh anak beliau yang merupakan tokoh masyarakat desa Kuntu. Berikut keterangan naskahnya:

Naskah M, berjudul Pathul Wahab dengan ukuran naskah 22, $3 \mathrm{x}$ $16,2 \mathrm{~cm}$. Sampul naskah terbuat dari kulit hewan berwarna hitam dan disimpan dalam boks bersampulkan kain bludru biru. Alas tulis terbuat dari kertas Eropa berwarna kecoklatan dengan watermark berbentuk bulan sabit bertumpuk tiga. Keterangan pada watermark dapat dijelaskan bahwa kertas dibuat di Venesia pada tahun 1783 oleh pabrik Vincenzio Formaleoni. Tidak ada penomoran halaman dalam teks. Kondisi naskah saat ini sebagian telah rusak dan sobek. Jumlah baris 25 baris perhalaman. Teks ditulis menggunakan aksara dan bahasa Arab. Warna tinta hitam dan rubrikasi menggunakan tinta warna merah. Dalam naskah terdapat secarik kertas yang bertuliskan bahwa naskah ini ditulis oleh Zakarya Yahya AlAnsori.

Berdasarkan data naskah yang diperoleh di dua tempat (rumah warga) di Kabupaten Kampar tersebut dapat disimpulkan bahwa hampir keseluruhan naskah beraksara dan berbahasa Arab. Terkait usia naskah, hampir semua naskah tidak mencantumkan kolofon, namun khusus naskah yang beralas tulis kertas Eropa, usia naskah dapat diketahui berdasarkan watermark yang tertera pada alas tulis tersebut. Untuk panduan keterangan watermark, peneliti memakai buku karya Edward Heawood (1950). Berikut keterangannya:

\begin{tabular}{|l|l|l|l|}
\hline No & Kode Naskah & Jenis Watermark & Identifikasi Tahun \\
\hline 1 & Naskah A & Giling, 1828 (?) & - \\
\hline 2 & Naskah G & - & - \\
\hline 3 & Naskah I & Budler & - \\
\hline 4 & Naskah J & Propatria & $\begin{array}{l}\text { Kertas dibuat di } \\
\text { Inggris pada tahun } \\
1764 \text { (kode 3712) }\end{array}$ \\
\hline 5 & Naskah K & c.l.b & - \\
\hline 6 & Naskah L & Fleur-de-Lis & $\begin{array}{l}\text { Kertas dibuat di The } \\
\text { Hague, Belanda oleh } \\
\text { E. Kempfer pada } \\
\text { tahun 1729 }\end{array}$ \\
\hline 7 & Naskah M & Bulan sabit & $\begin{array}{l}\text { Kertas di buat di } \\
\text { Venice pada tahun } \\
1783 \text { oleh pabrik } \\
\text { Vincenzio } \\
\text { Formaleoni (kode } \\
874)\end{array}$ \\
\hline
\end{tabular}

Informasi yang didapatkan dari table di atas, dari ketujuh naskah yang beralastuliskan kertas Eropa hanya tiga naskah yang dapat diidentifikasi keterangan tahunnya, yaitu naskah $\mathrm{J}$, L, dan M. Watermark dalam naskah 
lainnya, yaitu naskah A, G, I, dan K tidak ditemukan keterangan dalam buku Edward Heawood. Kaitannya umur naskah dengan watermark dapat digambarkan sebagai berikut, kertas yang sudah diproduksi pabrik saat itu langsung didistribusikan secara lintas negara, dari sini dapat diasumsikan bahwa perkiraan jarak waktu dari masa pembuatan kertas hingga kertas digunakan, yaitu 1-2 tahun (Fathurahman, 2015: 121).

\section{A. Simpulan}

Berdasarkan penelusuran awal yang telah dilakukan dapat diketahui beberapa informasi awal, (1) Hasil pendataan dapat disimpulkan, terdapat total 13 naskah yang berhasil di data di wilayah Kabupaten Kampar; naskah-naskah yang telah ditemukan merupakan milik pribadi masyarakat atas nama Abdul Latif dengan koleksi naskah berjumlah 12 naskah, dan Bosu Ani berjumlah 1 naskah. (2) Upaya yang dapat dilakukan untuk sementara ini melalui pendataan dalam bentuk deskripsi naskah dan digitalisasi naskah yang disimpan dalam CD. Berdasarkan deskripsi naskah dapat disimpulkan bahwa hampir keseluruhan naskah berbahasa dan beraksara Arab; hampir keseluruhan naskah merupakan naskah kitab, baik naskah hadist, potongan surah dalam Al-Qur'an, kumpulan doa-doa, maupun Al-Qur' an itu sendiri; hampir keseluruhan naskah tidak mencantumkan usia naskah, namun berdasarkan informasi watermark khusus naskah yang beralastuliskan kertas Eropa dapat diketahui perkiraan usia naskah.

\section{DAFTAR PUSTAKA}

Hamidy, U.U. 1983. "Naskah Kuno Daerah Riau". Laporan Penelitian. Pekanbaru: Fakultas Sastra Universitas Riau. 1985. "Naskah Melayu Kuno Daerah Riau”. Laporan Penelitian. Pekanbaru: Fakultas Sastra Universitas Riau.

Heawood, Edward. 1950. Watermarks I: Mainly of The $17^{\text {th }}$ and $18^{\text {th }}$ Centuries. Holland: The Paper Publications Society.

Ikram Achadiati. 1997. Filologia Nusantara, Jakarta: Pustaka Jaya.

Iswanto, K. (2015). Khazanah Naskah Kuna Kegamaan Islam di Propinsi Riau: Deskripsi Telaah Khusus pada Naskah Bertemakan Tauhid. Jurnal Lektura Keagamaan, 13 (2), 431-454.

Liaw Yock Fang. 2011. Sejarah Kesusastraan Melayu Klasik. Jakarta: Yayasan Obor Indonesia. 
Lubis, Nabila. 2001. Naskah, Teks dan Metode Penelitian Filologi. Jakarta: Yayasan Media Alo Indonesia

Mulyadi, Sri Wulan Rujiati. 1994. Kodikologi Melayu di Indonesia. Depok: Fakultas Sastra UI.

Mu'jizah dan Maria Indra Rukmi. 1998. Penelusuran Penyalinan Naskah-naskah Riau Abad XIX: Sebuah kajian Kodikologi. Jakarta: Program Penggalakan Kajian Sumbersumber Tertulis Nusantara, FSUI.

Roza, Ellya. 2011. Naskah Melayu. Pekanbaru: Yayasan Pusaka Riau

Saputra, Karsono. H.. 2008. Pengantar Filologi Jawa. Jakarta: Wedatama Widya Sastra.

Saidi, Shaleh. 2003. Melayu Klasik: Khazanah Sastra Sejarah Indonesia Lama. Denpasar: Laras-Sejarah.

Wieringa, E.P. 2007. Catalogue of Malay and Minangkabau Manuscripts, Vol. Two. Leiden: Leiden University Library.
Website:

Koto Perambahan.Tersedia: http:// detakkampar.co.id/blog/2014/11/21/ menggali-sejarah-kerajaan-kampardi/ [30 Oktober 2016]

Katkova, I.R. Dewaki Kramadibrata dan Munawar Holil. Dokumentasi dan Pendataan Naskah-naskah Indonesia di Rusia. Tersedia: http:// kampungbetawi.com/gerobog/pituah/ dokumentasi-dan-pendataan-naskahnaskah-indonesia-di-rusia/ [31 Oktober 2016]

Putra, Apria. 2011. . Syekh Abdul Ghani Batu Sorek-Kampar (18111961): Pemuka Ulama Naqsyabandiyah dan Auliya' yang Terbilang di Belahan Riau, ranah Minangkabau. Tersedia: http:// surautuo.blogspot.co.id/2011/03/ syekh-abdul-ghani-batu-basurekkampar.html [30 Oktober 2016] 